\title{
Judicial Activism in Brazil
}

\author{
Maria Claudia Trajano Marques De Souza Santos \\ Anhanguera University \\ Escola Paulista de Direito
}

\author{
Thais Jurema Silva
}

The purpose of this article is to provoke a debate about the possibilities and limits of judicial intervention in the other branches of the Republic. Judicial activism presupposes, broadly speaking, the failure to carry out public policies that guarantee the fundamental rights of Brazilian citizens by those responsible for it. Currently, the role of the Judiciary in granting fundamental rights constitutionally provided for has caused a reaction from the other powers. This is because, in these times where there is unprecedented ease in the access of information, it is important for political actors to keep the electorate's sympathy up to date. The initiative by the Judiciary in the performance of a function that was not primarily attributed to it by the Federal Constitution and has the capacity to attract protagonism to itself. Through research of doctrinal and jurisprudential positioning, we approach the legitimacy of this intervention from a legal perspective and the consequences of social order that arise from it. In addition, we show how judicial activism has taken on an important role in delivering justice in historic situations of inequality and segregation Finally, we conclude that judicial activism must be contemporized to fulfill the role of fundamental resource to correct omissions on the part of the Public Power capable of affecting the minimum existential to human dignity. The arbitrary or improper use of the Judiciary's ability to interfere in other powers may configure its politicization, affect its duty of exemption, culminating in the imbalance of the rule of law.

Keywords: judicial activism, existential minimum, reserve of the possible

\section{INTRODUCTION}

The evolution of social relations occurs in a very dynamic way, considering patterns not always uniformly understandable by society.

At the end of the last century, relationships between people with sexual orientation different from the so-called heterosexual were not socially accepted, with the degree of tolerance and respect that is accepted today. The episodes of violence resulting from prejudice against homosexuals are public facts; they were daily reported in the press.

Obviously, such truculent practices still play a major role the reality of people of various sexual orientations, however, society, evidently more evolved in the recognition of the values inherent to human dignity, has shown itself to be increasingly intolerant of conduct of this nature.

In this scenario, the judiciary explained its first position on the case in 2011 , through ADI $4.277^{1}$, having held at the time that there would be no reason not to have the necessary recognition of homosexual 
unions if the fundamental elements that characterize it legally were exposed in the relationship, taking this trial, the main milestone in the legal evolution on the subject in Brazilian territory. It is worth noting that in this scenario, the Judiciary, by attributing to homoaffective unions the exclusive rights of heteroaffective unions, played an important role.

The disrespect to homosexuals was not only evident in society's behavior; in the public sphere there was also a lack of legal support, so that public policies in favor of the class were not discussed and the main legal instrument at our disposal - the Federal Constitution - whose role is to confer recognition and protection to the fundamental rights of all citizens, did not even attribute to homosexual relations the possibility of obtaining the status of family.

As a consequence, the abandonment of the surviving partner before the death of his partner was commonly reported, since he had no right to inherit the jointly constituted estate.

On the occasion of the oral vote given in the trial of ADPF 132 and ADI 4.277 already mentioned above, in which the government of the State of Rio de Janeiro requested the application of the legal regime of unions, provided in Article 1. 723 of the Civil Code, to homo-affective unions of civil servants of Rio de Janeiro, Justice Ricardo Lewandowiski recognized the limits imposed on the Judiciary regarding the application of the law, but also recognized the necessary activism in order to guarantee the fundamental rights of the individual; in this case, the right to human dignity.

This position has opened a margin for the judiciary to play a leading role in suppressing omissions in the legislative and executive spheres, given the inexistence of laws that can be directly applied (unless by analogy), and the lack of educational policies to change the behavior of society.

Nowadays, any citizen, whatever the sexual orientation to which he or she adheres, has preserved his or her right to unite affectively with whomever he or she wishes; moreover, his or her property rights are preserved in case of death or divorce, this being possible due to the judicial activism observed in the judgments handed down over time.

The paradigmatic example represents one among several that reveal the timely and effective action on the part of the Judiciary, which is called judicial activism. There are, however, those who defend the strict limitation of this action.

The watchful eye of all institutions to social demands only becomes effective if there are those who welcome them. The legislative process involves bureaucratic procedures, which does not always meet social needs in a timely manner. The late fulfillment of social demands is not able to balance inequalities; on the contrary, it sharpens injustices and segregation even more.

The article will focus on issues related to the possibility of interference between the powers, especially that which occurs by initiative of the Judicial Power in the others, besides reproducing paradigmatic episodes in which this interference proved decisive in the effectiveness of constitutional guarantees in favor of social groups historically or otherwise segregated by the actions of the Public Power.

The present study is based on the connection of practiced doctrine together with consolidated jurisprudence, demonstrating the legitimacy of judicial activism, its limits and outcome in the social environment.

\section{SEPARATION OF POWERS}

The separation of powers constitutes a fundamental pillar in what is expected of a democracy; moreover, the respect for the attributions conferred on them, without unjustified OR arbitrary interference is what makes the ideal of independence of institutions effective.

History has already proven that the contempt for the constitutional foundation of the harmonious division of powers in a society counts on the strong possibility of authoritarianism and arbitrariness on the part of the government.

There is a consensus in the world that the preservation of democracy necessarily passes through the recognition and respect of the division of attributions among institutions that will act independently and harmoniously. 
It happens, however, that the interference of one power in another on certain occasions is necessary to curb possible abuses. The modern vision of what is understood as democracy demands that the division of powers and their independence should not be treated in an absolute manner. It remains incontrovertible that the reciprocal interference of the powers as a way of controlling their actions is fully legitimate and republican. This does not mean, however, that such interference does not generate reactions of resistance in the members of the controlled institution; obviously, the control is not always harmonious and adequate; there are abuses even in the exercise of the right of interference by the powers.

There are those who maintain that the possibility of intervention by the Executive in the activity of the legislative power brings with it fearful legal insecurity arising from the fact that the main activity assigned to the person occupying the position of head of the Executive consists in the practice of acts of administration; the legislative attribution should be given in exceptional form. The inversion of this order, in accordance with what the aforementioned doctrine defends, brings about an affront to the pillars of democracy, from which comes the issue of legal insecurity.

The assumption of attributions of one power by another may eventually generate, what is understood as abuse; however, denying such a possibility harms the basic principles of the democratic rule of law and makes certain the occurrence of excesses and arbitrariness, since power would be concentrated in the hands of whoever holds it.

\section{JUDICIAL ACTIVISM}

In an objective way, judicial activism arises from the need to defend rights not described in the rule, leading to a more active posture on the part of the Judiciary, in order to lead the initiative for the defense of collective rights, using judicial decisions as a means to fill legislative omissions.

Observing this, we can see that the judge must look at the infra-constitutional norms with a refined criticality, adequate to the new constitutional paradigms; no longer behaving as a mere applier of the law to the case at hand, but as a determining agent in the new social reading, taking upon himself the responsibility of judging the case according to social evolution.

In this way, the discretionary nature present in the activities of judges is the major argument that legitimizes the judge's proactivity and the main object of the positivists' sharp criticism.

This is the understanding of Justice Barroso:

"For positivists, the judge has no discretionary power when a clear and established rule is available. However, for Hart, in those cases of unclear rules, of "open texture", the judge must use the discretionary power to judge (strong sense). Dworkin suggests that Hart defends the idea that judges are in no way bound by standards other than rules, when he of a discretionary power left by language, in situations where the rules are unclear due to their open texture." (Barroso, 2018)

The proactivity that confronts the positivism faithfully practiced in times past, manifests itself in the judicial activism existing today. It should be clarified in this regard that the positivity of the law still prevails with the immediate application of legal provisions. However, social demands require a legal position in reasonable time to meet the expectation of brief justification, which is not consistent with a judiciary power limited to the restricted application of the law to the case at hand.

This modern vision of the actions of the Judiciary is also characterized by a broad view of the Federal Constitution, expanding its meaning to reach fundamental rights relegated by legislative omission.

What is pointed out as negative in judicial activism is the fact that it occurs in the space that the Legislature should occupy, but did not, transmitting to another organ of state power the legitimacy to occupy that space.

The omission on the part of the Executive and Legislative powers in the proposal and elaboration of public policies in favor of society reveals the gaps in the country's political system, which ends up weakening its structures. 
The ideal system requires balance in political action by the judiciary; that is, the active judicial decisions should be used with criticality, revealing respect for the preservation of autonomy and independence of powers.

In any case, the opposition made to judicial activism finds firm ground. While recognizing the importance of active judicial action, its critics point out some pitfalls that deserve attention.

The Minister Luis Roberto Barroso presents the following criticism of judicial activism: "risks to legitimacy, in the undue politicization of the justice and in the limits of the institutional capacity of the Judiciary. " (Barroso, 2018)

When reflecting on the risks for democratic activity, Minister Luis Roberto Barroso questions the origin of the legitimacy of a body, whose members were not elected by popular will, to invalidate acts practiced by members of the Legislature and the Executive, whose members have occupied their respective positions through the vote of citizens manifested in democratic elections.

The aforementioned reflection makes sense to the extent that the Judiciary is not a political organ. Its function in the Republic is to promote the application of justice in terms of what has already been established as a legal rule by the power that is responsible for legislating.

It happens that the division of powers, as already seen, must be treated taking into account the need for eventual interference by the Judiciary, which is responsible for interpreting the law, in the spheres of the other powers with the purpose of invoking social balance. The discretionary power of the judge grants him precisely the prerogative of identifying such gaps and applying, making use of the resources provided for in the legal system itself, the appropriate remedy to fill them.

The second criticism made by Luis Roberto Barroso refers to the risk of politicizing justice. In this context, it is assumed that Law is not politics. The author argues that attacking a certain judicial decision on the grounds that it is a political decision ends up emptying the judicial activity.

In fact, the judge counts on subjective criteria that mark the paths of his conviction. It is impossible to dissociate the one who holds the power to decide from his moral and ethical values, which will influence his decision. By affirming that Law is not politics, we intend to clarify that the judge should not be allowed to make biased decisions that go against the constitutional duty to act with impartiality.

In order to ensure that the magistrate's political function does not exceed the limits established by the duty of impartiality, it is necessary that the judge does not admit the prevalence of his political convictions when rendering his decision; on the contrary, he must adhere to the laws and the Federal Constitution. In addition, he must pay attention to the fact that the Legislative Branch is the one that actually has the competence to make laws; this implies presuming, therefore, that the exercise of this function has observed the procedural and material criteria necessary to attribute validity to the legal rules.

It is also important that the judges do not intend to assume populist positions that aim to acquire the sympathy of society. The application of the law may lead, at a given moment, to the opposition of majority positions, but the protection of fundamental guarantees is necessary.

The third criticism verified by Luis Barroso (2018) regarding judicial activism refers to the institutional capacity of the judiciary.

About this, it is assumed that the existence of a clear division of functions between the institutional powers in a democratic republic goes through the recognition that such powers have not necessarily given the completeness of the fundamental technical competence for the analysis of how much it is given to solve. Specifically with regard to the Judiciary, it has always been incumbent upon it to state the law. However, it is important to consider the limits of its institutional capacity in order to recognize, if this is the case, that it lacks the technical resources of the other powers.

Another face of the institutional capacity of the Judiciary, as explained by the Minister, consists in the fact that the magistrate is responsible for the attribution of the Law, and should consider, eventually, the individual sacrifice for the sake of conferring protection to the collectivity.

The protection of public policies that favor the majority should prevail when faced with individual benefits. Such a phenomenon the writer has termed 'systemic effect risk' from which he concludes that: 
"the Judiciary almost always can, but should not always interfere. (...) Having a careful evaluation of one's own institutional capacity and opting not to exercise power, in spontaneous self-limitation, rather elevates than diminishes."3 (Barroso, 2018)

In fact, the exceptional use of the right to interfere in attributions conferred to other powers imposes the adoption of important criteria by the judging power.

The debate about the granting of rights considering, for example, the principle of the reserve of the possible has high level arguments to defend or to oppose it. Reasonableness in the act of deciding reveals itself as the challenge to judicial activism.

\section{JUDICIAL ACTIVISM TO GUARANTEE SOCIAL RIGHTS AND THE IMPOSSIBLE RESERVE}

It is the duty of the State to guarantee the effectiveness of the social rights foreseen in article 6 of the Federal Constitution, among which are health, education, leisure, work, food, and housing, among others.

The provision of article 6', however, is characterized by what is called programmatic rule, i.e., its effectiveness demands, necessarily, the planning of public policies by the State that provide for actions that collectively privilege the minorities most affected by inequality present in the country.

The concept of public policies brought by Ronald Dworkin clearly reveals his goal:

"That type of standard that sets a goal to be achieved, usually an improvement in some economic, political or social aspect of the community (although some goals are negative in that they stipulate that some current state must be protected against adverse changes." (Barroso, 2018)

The attainment of the purpose intended by Article 6" of the Federal Constitution demands, in addition to planning, budgetary resources and political will on the part of the Executive and Legislative branches, which are responsible for proposing and defining public policies to this end. Moreover, the political will requires a careful analysis of which social sector the implementation of any public policy action capable of promoting any guarantee enshrined in Article 6" of the Federal Constitution is intended for.

It happens however, that without disregarding the lack of political will many times verified in the Brazilian political system, the budgetary reserve constitutes the most used justification invoked by part of the Executive and Legislative powers for the omission in the implementation of public policies. Of this situation, it is worth highlighting what is verified in the health sector.

The Public Authorities are routinely the target of lawsuits that seek the granting of an order for the delivery of medication or medical treatment. When granting the request, the judge recognizes that health is a fundamental right, one of the corollaries of human dignity, which is why it cannot be set aside in favor of the principle of the reserve of the possible.

Although the right to health is a fundamental guarantee in the Federal Constitution, the question of the confrontation of this right with the principle of the reserve of the possible has generated debates. This is because the concession of individual guarantees, although fundamental to the maintenance of human dignity, cannot prevent the implementation of public policies of collective scope. The analysis that is made is financial; where to allocate the resource? To what extent does the individual right to health have to prevail in detriment of collective protection?

The granting of an order for the delivery of medicine or access to certain medical treatment evidences the phenomenon of judicial activism, since the judge is responsible for weighing the conflicting rights; in this case, concluding to protect the individual right.

In fact, the inertia on the part of the State in fulfilling its role in the delivery of fundamental rights authorizes the Judiciary to do so and, in this case, it is necessary, in fact, to protect life, the greatest human hem, with everything that gives it dignity. 


\section{CONCLUSION}

Judicial activism currently represents effective recourse in repairing omissions by the Executive and Legislative branches in the delivery of constitutionally provided fundamental rights, as exemplified in the examples cited in this text, in legislative omissions and judicial activism, led to the guarantee of fundamental rights of homosexuals throughout the Brazilian territory.

Based on this, in a democratic republic, a balanced interference between the powers is opportune, since it is not always possible for them to fulfill their institutional attributions.

Any interference, however, demands order and the recognition of the limitation of the Judiciary's own capacity, under penalty of having affected its duty of exemption, of political abstention, culminating in the unbalance of the Rule of Law.

At any rate, in a social context in which individuals suffer from the absence of public policies capable of guaranteeing the minimum for a dignified human existence, under the frequent justification of a deficit budget, it is up to the Judiciary, as the body responsible for enforcing the Federal Constitution, to assume the leading role in the effective delivery of social rights to citizens.

Human life is the highest good and should not suffer unnecessary damage or threat as a result of legislative omission. Faced with the lack of planning and action to implement a public policy that benefits the community on the part of the powers that be, the Judiciary, in its role as guarantor of rights, must do so, obviously recognizing its limits.

\section{ACKNOWLEDGEMENT}

Translated \& edited by American Publishing Services (https://americanpublishingservices.com/).

\section{ENDNOTES}

1. ADI 4277, Relator(a): AYRES BRITTO, Tribunal Pleno, julgado em 05/05/2011, DJe-198 DIVULG 13-10- 2011 PUBL1C 14-10-2011 EMENT VOL-02607-03 PP-00341RTJ VOL-00219-01PP-00212.

2. CARVALHO, Emani Rodrigues de, 2004, apud SILVA, Alexandre Garrido da; VIEIRA, Jose Ribas. Justia tnmsicional, direitos humanos e a seletividade do ativismo judicial no Brasil Revista da Faculdade de Direito Candido Mendes, Rio de Janeito, v. 1, n. 13, de.z. 1996. p. 53-54.

3. BARROSO, Luis Roberto. JUDICIALIZA $<$;AO, ATIVISMO JUDICIAL E LEGITIMIDADE DEMOCRATICA, Disponlvel em file·II IC · II Jsers /TFZ0/o20\%20C/Down1oads /Dialpe(ludjciaJizacaoAtiyisrnoludicialFI egitimidadeQemocra-124286.pdf. Acesso em 27 de Maio de 2020.

4. DWORKIN, Ronald. Levando os direitos a serio. Sao Paulo: Martins Fontes, 2002., p. 37. 